Plates XVII-XXI of the memoir provide ample and brilliant illustration, both in surface and sectional view, of the earlier stages of blastomeric segmentation in the Prototheria, and lead one to anticipate eagerly the authors' future elucidation of the succeeding stages of development and above all of the beginnings of germ-layer differentiation.

Only those with some experience of the technical difficulties involved in the collection, preparation and sectioning of material at once both rare and refractory to treatment can fully appreciate the success with which those difficulties have been surmounted, as well as the excellence of the figures with which the memoir is so abundantly adorned.

\section{UPWARD MOVEMENT OF SALT IN THE PLAN'T}

Prof. D. R. Hoagland, T. C. Broyer and P. R. Stout of the University of California, Berkeley, read a paper dealing with the upward movement of salt in the plant, with special reference to the metabolic activities of roots, before the U.S. National Academy of Sciences at its annual meeting held during April 22-23.

Previous investigation has proved that accumulation of salt by the plant from the nutrient medium depends on aerobic metabolism of root cells. The relation of root activities in salt accumulation to movement of salt to the shoot has now been studied from several points of view. For certain purposes it has been necessary to conduct experiments over short periods of time with tracer elements, not initially present in the plant. Bromide ions and salts of the radioactive isotopes of bromine, sodium, phosphorus and potassium have been utilized. One of the authors (P. R. Stout) has developed technique for showing in graphic manner the general distribution of radioactivity in the plant by effects produced on X-ray films.

Several general cases of salt movement are recognized: $(a)$ under influence of root pressure, $(b)$ as affected by transpiration, (c) movement under conditions conducive to root injury produced by high salt (for example, sodium chloride) concentrations. Xylem exudates may build up very rapidly concentrations of salt much higher than those of the external solution. This may occur even before the roots have attained their maximum capacity for salt accumulation. The phenomenon is related to oxygen supply to roots, concentrations and kind of salt supplied, and indirectly to photosynthesis. Soluble organic nitrogen compounds and organic acid can also move in the exudate dependent on metabolic activities of the root and nature of salt supplied. The effects of $\mathrm{KHCO}_{3}$ are particularly interesting in connexion with organic acid metabolism. Young active barley plants may absorb and translocate nutrient ions almost as readily in the dark as in the light, over brief experimental periods. Such plants may grow normally for some time with nutrients supplied only during the diurnal dark periods. With large plants, or those less capable of developing root pressure, rapid upward movement of salt depends on transpiration, which may thus indirectly influence absorption of salt by the root. Further evidence was obtained on the path and rate of upward and downward movement of phosphate by the use of radioactive phosphorus.

\section{APPOINTMENTS VACANT}

APPLICATIONS are invited for the following appointments on or before the dates mentioned:

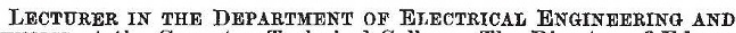
PHYsics at the Coventry Technical College-The Director of Education, The Council House, Coventry (September 11)

ASSISTANT LEOTURER IN THE DEPARTMENT OF MATHEMATICS-The Principal, Technical College, Huddersfleld (September 12).

Lectorer in Crvil ENGINEERING-The Secretary, Technical College, Sunderland (September 16).

Graduate Teacher For Science Subjects, preferably with PHYSICs as a main subject-The Principal, Luton Technical College, ark Square, Luton (September 17).

IRRIGATION ENGINEER for the Government of Ceylon Irrigation Department-The Crown Agents for the Colonies, 4 Millbank, S.W.1 (quoting M/9394) (September 27).

ASSISTANT TO TEACH ENGINGERING DRAWING, ENGINEERING ScIEnce, etc.--The Registrar, Technical School for Boys, Wimbledon, S.W.19.

\section{REPORTS AND OTHER PUBLICATIONS}

(not included in the monthly Books Supplement)

\section{Great Britain and Ireland}

Memoirs of the Cotton Research Station, Trinidad. Series A : Genetics. No. 16: (a) The Genetic Interpretation of Plant Breeding Problems, by J. B. Hutchinson; (b) Inheritance of Quantitative Characters and Plant Breeding, by V. G. Panse. Pp. 34. (London :
Empire Cotton Growing Corporation.) 28. 6d.

Medical Research Council : Committee on Traumatic Shock and on Blood Transfusion. M.R.C. War Memorandum No. 1: The Treatment of Wound Shock. (Instructions produced in co-operation with the Army Medical Service.) Pp. ii 20 . (London: H.M. Stationery Office.) $4 d$. net.

\section{Other Countries}

Report of the Forest Department of British Honduras for the Year 1939. Pp. 22. (Belize : Forest Department.)

U.S. Department of Agriculture. Technical Bulletin No 711 Economic Status of the English Sparrow in the United States. E. R. Kalmbach. Pp. $66+3$ plates. 15 cents. Technical Bulletin No. South Atlantic States. By W. J. Reid, Jr. Pp. 44. 10 cents. (Washington, D.C. : Government Printing Office.) Field Museum of Natural History. Anthropology Leaflet 34 : Ancient Seals of the Near East. By Richard A. Martin. Pp. 46. (Chicago: Field Museum of Natural History.) 25 cents. [198

Imperial College of Tropical Agriculture. Ninth Annual Report on Cacao Research, 1939. Pp. 52. (Trinidad : Imperial College of Tropical
Agriculture.) 58.

Bernice P. Bishop Museum. Bulletin 160: Ethnology of Easter Island. By Alfred Métraux. Pp, vî́ $+432+7$ plates. Builetin 165: Zonitid Snails from Pacifle Islands, Part 2: Hawaiian Genera of Microcystinae. By H. Burrington Baker. Pp. iii $+105-202+$ plates 21-42. Bulletin 167: Report of the Director for 1939. By Peter H. Buck (Te Rangi Hiroa). Pp. 42. (Honolulu: Bernice P. Bishop Occasional Papers of Bernice P. Bishop Museum. Vol. 15, No. 15: Four New Microcryptorhynchus from the New Hebrides and Caroline Islands (Coleoptera, Curculionidae). By Elwood C. Zimmerman. Pp. (Ruppiaceae) from the Tropical Pacific. By Harold St. John and F. Raymond Fosberg. Pp. 175-178. Vol. 15, No. 17: Additional Notes on the Archaeology of Fanning Island. By Kenneth P. Emory. Pp. 179-190. Vol. 15, No. 18: Scolytidae and Platypodidae of the Mangarevan Expedition. By C. F. C. Beeson. (Mangarevan Expedition, Publication 30.) Pp. 191-204. Vol. 15, No. 19: Notes on the Morphology and Sexuality of the Terrestrial Nemertean, Geonemertes palaensis. By W. R. Coe. (Microncsian Wxpedition, Publication 4.) Pp. 205-212. Yol. 15, No.20: Notes on Micronesian Rubiaceac. By F. R. Fosberg. (Micronesian Expedition, Publication 3.) Pp. 213226. Vol. 15, No. 21: The Genus Ficus (Moraceae) in Southeastern Polynesia. By V. S. Summerhayes. (Mangarevan Expedition, Publication 33.) Pp. 227-228. Vol. 15, No. 22: Hawailan Plants named by Endlicher in 1836. By Harold St. John. (Hawaiian Plant Studies. 8.) Pp. 229-238. Vol. 15, No. 23: Some New Species of Araucaricola Lea from the South Pacific (Coleoptera, Tenebrionidae). By K. G. Blair. Pp. 239-242. Vol. 15, No. 24: Thysanoptera from New Guinea and New Britain. By Dudley Moulton. Pp. 243-270. Vol. 15, No. 25: Synopsis of the Genera of Hawaiian Cossoninae, with Notes on their Origin and Distribution (Coleoptera, Curculionidae). By Elwood C. Zimmerman. Pp. 271-294. Vol. 15, No. 26: The Isopod Crustacea of the Hawaiian Islands (Chelifera and Valvifera). By Milton A. Miller. Pp. 295-322, Vol. 15, No. 27: Mosses of Southeastern Polynesia. By Edwin B. Bartram. (Mangarevan Expedition, Publication 34.) Pp. 323-350. (Honolulu: Bernice P. Bishop Museum.)
[198 Tanganyika Territory: Department of Agriculture. Fifth Anmual Report of the Coffee Research and Experiment Station, Lyamungu, Moshi, 1938. Pp. 40. (Dar es Salaam: Government Printer.)

18. 6 d.
U.S. Office of Education: Federal Security Agency. Bulletin 1940,
No. 4, Part 1: Elementary Education-What is It? By Helen K. No. 4, Part 1 : Elementary Education-What is It? By Helen K. Office.) 10 cents. 